\title{
Efek pemberian metilprednisolon oral terhadap gambaran histopatologik hati tikus wistar (Rattus norvegicus)
}

\author{
${ }^{1}$ Muhammad Rifaldi \\ ${ }^{2}$ Poppy M. Lintong \\ ${ }^{2}$ Meilany F. Durry \\ ${ }^{1}$ Kandidat Skripsi Fakultas Kedokteran Universitas Sam Ratulangi Manado \\ ${ }^{2}$ Bagian Patologi Anatomi Fakultas Kedokteran Universitas Sam Ratulangi Manado \\ Email: daariymuhammad@gmail.com
}

\begin{abstract}
Drug-induced liver injury (DILI) is an adverse drug reaction which vary in its clinical manifestations, ranging from an asymptomatic increase in liver enzymes to fulminant hepatic failure. Several drugs can cause DILI, one of which is corticosteroid. Methylprednisolone (MT) is a kind of corticosteroid drug which is considered to be a safe drug and it is not believed to cause DILI and often used for the treatment of severe hepatitis. However, there are some reports of DILI in patients treated with high-dose MT. The objectives of this study was to determine the effect of oral administration of MT on liver's histological changes of witar rats. This study was using 15 rats which were divided into 3 groups; 1 negative control group (group A) and 2 treatment groups (group B and group C). Group B was given a low-dose oral MT, $2 \mathrm{mg}$ /day, while group C was given oral high-dose MT, $4 \mathrm{mg} /$ day for 14 consecutive days. The results showed steatohepatitis features in both low-dose and high-dose MT administration groups. Histopathological features of both treatment groups are similar. Qualitatively, high-dose MT group showed worse histopathological features than the low-dose MT group. Conclusion: Administration of MT by $2 \mathrm{mg} /$ day and $4 \mathrm{mg} /$ day may induced steatohepatitis in wistar rat's liver.
\end{abstract}

Keywords: methylprednisolone, liver histopathological features

\begin{abstract}
Abstrak: Drug-induced liver injury (DILI) atau cedera hati akibat obat merupakan reaksi efek samping obat dengan manifestasi klinis yang beragam, mulai dari peningkatan enzimenzim hati yang bersifat asimptomatik sampai dengan timbulnya gagal hati fulminan. Banyak obat-obatan yang dapat menyebabkan DILI, salah satunya adalah golongan kortikosteroid. Metilprednisolon (MT) adalah obat golongan kortikosteroid yang dianggap sebagai obat yang aman dan tidak diyakini dapat menyebabkan DILI, bahkan sering digunakan untuk terapi pasien hepatitis berat. Akan tetapi, beberapa klinisi melaporkan kasus DILI pada pasien-pasien yang diterapi dengan MT dosis tinggi. Penelitian ini bertujuan untuk mengetahui efek pemberian MT oral terhadap perubahan histologik hati tikus wistar. Jenis penelitian yang dilakukan adalah eksperimental laboratorik menggunakan 15 ekor tikus yang dibagi dalam 3 kelompok; 1 kelompok kontrol negatif (kelompok A) dan 2 kelompok perlakuan (kelompok B dan kelompok C). Kelompok B diberikan MT oral dosis rendah sebanyak $2 \mathrm{mg}$ /hari sedangkan kelompok C diberikan MT oral dosis tinggi sebanyak 4 $\mathrm{mg} /$ hari setiap hari selama 14 hari berturut-turut. Hasil penelitian menunjukkan gambaran yang sama secara mikroskopik pada kedua kelompok perlakuan yaitu terjadinya steatohepatitis. Tetapi secara kualitatif, kelompok tikus yang mendapatkan MT dosis tinggi memberikan gambaran histopatologik yang lebih jelek dibandingkan kelompok yang diberi dosis rendah. Simpulan: Pemberian metilprednisolon dosis $2 \mathrm{mg} / \mathrm{hari}$ dan dosis $4 \mathrm{mg} / \mathrm{hari}$ dapat mencetuskan terjadinya steatohepatitis pada hati tikus wistar.
\end{abstract}

Kata kunci: metilprednisolon, gambaran histopatologik hati 
Drug-induced liver injury (DILI) atau cedera hati akibat obat merupakan reaksi efek samping obat yang sangat penting dan sering terjadi dalam praktek klinik. Manifestasi klinisnya sangatlah beragam, mulai dari peningkatan enzim-enzim hati yang bersifat asimptomatik sampai dengan timbulnya gagal hati fulminan. ${ }^{1}$ Banyak obat-obatan yang dapat menyebabkan DILI, diantaranya adalah obat-obatan dari golongan kortikosteroid. ${ }^{2}$

Metilprednisolon (MT) adalah obat golongan kortikosteroid yang termasuk dalam kelompok adrenokortikosteroid sintetik. ${ }^{3}$ Steroid dianggap sebagai obat yang aman dan tidak diyakini dapat menyebabkan DILI, bahkan sering digunakan untuk terapi pasien hepatitis berat. ${ }^{4}$ Mekanisme MT menyebabkan DILI sampai sekarang masih belum diketahui dengan jelas dan pada beberapa keadaan hanya berkaitan dengan kejadian imunosupresi dimana terjadinya reaktivasi infeksi dari virus hepatitis B. ${ }^{5}$

Beberapa klinisi melaporkan kasus terjadinya DILI pada pasien-pasien yang diterapi dengan MT. Berdasarkan laporan kasus yang ada, kejadian DILI akibat penggunaan MT terjadi pada pasien-pasien yang mendapatkan pulse therapy atau terapi dosis tinggi secara intravena kemudian pasien tersebut menunjukkan gejala hepatotoksisitas selama terapi diberikan. ${ }^{1,4,5}$ Dari hasil penelitian lain, didapatkan pula bahwa pemberian MT secara intravena memiliki efektivitas yang sama dengan MT yang diberikan secara oral. $^{6}$

Berdasarkan hal tersebut di atas, maka penulis tertarik melakukan sebuah penelitian eksperimental untuk melihat bagaimana efek pemberian MT secara oral terhadap gambaran histopatologik hati tikus wistar (Rattus norvegicus).

\section{METODE PENELITIAN}

Jenis penelitian yang dilakukan adalah penelitian eksperimental laboratorik. Penelitian ini dilakukan di Laboratorium Riset Biomedik dan Patologi Anatomi
Fakultas Kedokteran Universitas Sam Ratulangi Manado pada bulan September sampai Desember 2016. Subjek penelitian ialah 15 ekor tikus wistar jantan spesies Rattus norvegicus berumur 2-3 bulan dengan berat rata-rata 200 gram. Tikus wistar kemudian dibagi menjadi 3 kelompok; 1 kelompok kontrol negatif (kelompok A) dan 2 kelompok perlakuan (kelompok B dan kelompok C) yang masing-masing terdiri dari 5 ekor tikus. Kelompok A merupakan kelompok kontrol negatif yang tidak diberikan perlakuan apapun melainkan hanya diberikan pakan ternak AD2 dan minum dari air keran selama 14 hari. Kelompok B diberikan MT oral dosis rendah sebanyak $2 \mathrm{mg} / \mathrm{hari}$ sedangkan kelompok $\mathrm{C}$ diberikan MT oral dosis tinggi sebanyak $4 \mathrm{mg} / \mathrm{hari}$. Kedua kelompok perlakuan diberikan intervensi setiap hari selama 14 hari berturut-turut. Semua hewan uji kemudian diterminasi pada hari ke-15.

Dosis metilprednisolon yang digunakan dalam penelitian ini dihitung menggunakan angka konversi dosis manusia ke hewan sesuai animal equivalent dose dengan mempertimbangkan luas permukaan tubuh. ${ }^{6}$ Berdasarkan penelitian sebelumnya, MT baik oral maupun intravena memiliki efikasi yang sama. ${ }^{7}$ Untuk konsumsi dosis standar pada manusia, biasanya digunakan dosis bervariasi antara 2-60 mg/hari. ${ }^{8}$ Dosis MT untuk penelitian eksperimental dengan menggunakan tikus berkisar antara 8-20 $\mathrm{mg} / \mathrm{kgBB}$ tikus per hari dan penelitian ini meggunakan $10 \mathrm{mg} / \mathrm{kgBB}$ tikus sebagai dosis standar (rendah) dan $20 \mathrm{mg} / \mathrm{kgBB}$ tikus sebagai dosis tinggi dengan acuan berat badan tikus pada penelitian ini adalah 200 gram dan berat badan manusia $60 \mathrm{~kg}$. ${ }^{6,9}$

Metilprednisolon yang digunakan dalam penelitian ini adalah MT tablet $4 \mathrm{mg}$ yang kemudian dihaluskan dengan penggerus obat lalu dicampur dengan air mineral hingga sediaan menjadi $2 \mathrm{mg} / \mathrm{ml}$ air dan $4 \mathrm{mg} / \mathrm{ml}$ air. Sediaan obat kemudian diberikan secara oral menggunakan sonde lambung khusus untuk tikus. 


\section{HASIL PENELITIAN Kelompok A}

Tikus wistar dalam kelompok A merupakan kontrol negatif dimana pada kelompok ini, tikus tidak diberi perlakuan selama 14 hari berturut-turut kemudian diterminasi pada hari ke-15. Pada pemeriksaan jaringan hati menggunakan mikroskop, umumnya gambaran histologik yang diperoleh adalah gambaran sel hati yang normal. Lobulus hati berbentuk heksagonal dan pada bagian tengah terdapat vena sentralis yang dikelilingi selsel hati . Sel-sel hati tersusun radier dan rapih serta pada bagian sudut antarlobulus terdapat segitiga Kiernan yang terbentuk dari vena porta hepatika, arteri hepatika dan juga duktus biliaris (Gambar 1).

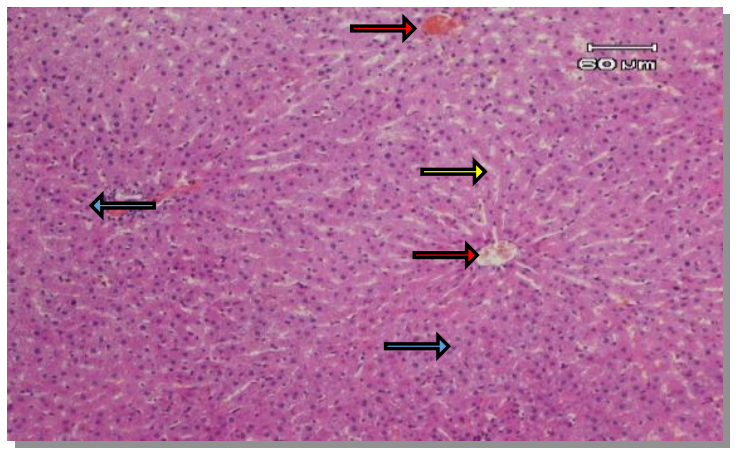

Gambar 1. Gambaran mikroskopik hati tikus wistar kelompok A (pembesaran 10x10). Panah merah: vena sentralis yang normal dan tidak menunjukkan adanya tanda pelebaran ataupun kongesti; panah kuning: sinusoid; panah biru: menunjukkan sel hati yang normal tersusun poligonal radier dan teratur.

\section{Kelompok B}

Tikus wistar dalam kelompok B (kelompok perlakuan 1) berjumlah 5 ekor yang semuanya mendapatkan perlakuan atau intervensi berupa pemberian metilprednisolon oral dosis rendah sebesar $2 \mathrm{mg} /$ tikus/hari selama 14 hari dan diterminasi hari ke-15. Secara umum, seluruh sampel jaringan hati dalam kelompok ini memperlihatkan gambaran yang mirip satu sama lainnya. Terlihat adanya tanda-tanda peradangan jaringan hati seperti sinusoid, vena sentralis, vena porta dan arteri hepatika juga segitiga Kiernan yang mengalami pelebaran (kongesti) dan terdapat banyak agregat sel- sel radang limfosit dan PMN serta ada perdarahan intrahepatik. (Gambar 2.1).

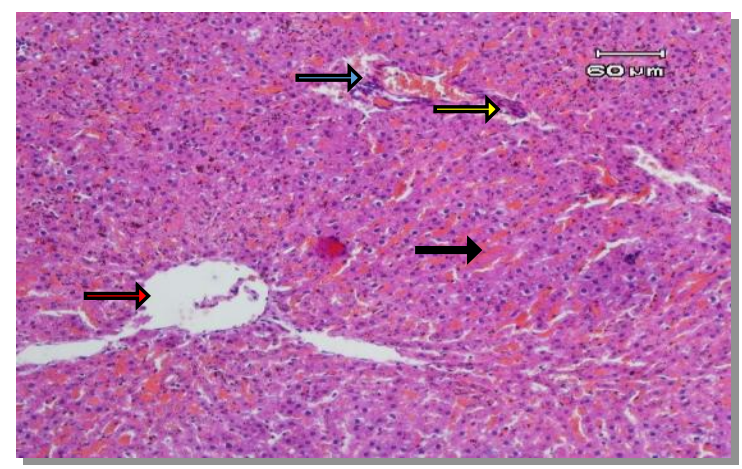

Gambar 2.1 Gambaran mikroskopik hati tikus wistar kelompok B (pembesaran 10x10). Panah merah: vena sentralis yang melebar; panah biru: segitiga Kiernan melebar; panah kuning: agregat sel radang sekitar segitiga keernan; panah hitam: fibrin eritrosit.

Jaringan hati tikus pada kelompok ini juga tampak mengalami degenerasi perlemakan yaitu adanya steatosis mikrovesikular (sel hati dengan sitoplasma bervakuol) dan beberapa steatosis makrovesikular yang tersebar secara fokal hanya pada bagian perifer dari jaringan hati. (Gambar 2.2).

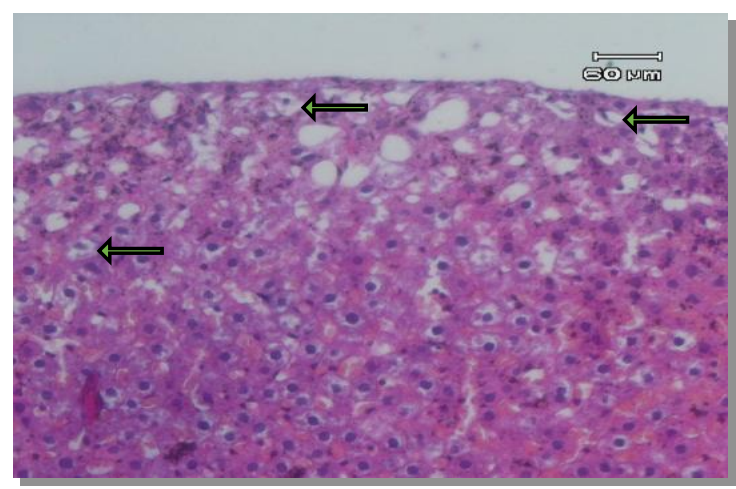

Gambar 2.2 Gambaran mikroskopik hati tikus wistar kelompok B (pembesaran 10x40). Panah hijau: perlemakan sel hati berupa mikrovesikular steatosis dan ada beberapa makrovesikular steatosis yang terlokalisasi hanya pada bagian perifer.

\section{Kelompok C}

Tikus wistar dalam kelompok C (kelompok perlakuan 2) diberikan metilprednisolon oral dosis tinggi sebesar 4 $\mathrm{mg} /$ tikus/hari selama 14 hari berturut-turut dan diterminasi pada hari ke-15. Hasil pengamatan mikroskopik sampel jaringan 
hati pada kelompok ini memperlihatkan adanya gambaran yang mirip dengan kelompok B. Hanya saja pada kelompok ini secara kualitatif gambaran histopatologik tampak lebih jelek. Banyak sel-sel yang mengalami steatosis, peradangan lebih luas dan terdapat pula tanda-tanda regenerasi dari sel hati.

Tampak jelas tanda-tanda peradangan jaringan parenkim hati seperti kongesti, pelebaran vena sentralis, vena porta dan arteri hepatika. Terlihat pula adanya pelebaran dari komponen segitiga Kiernan, pelebaran sinusoid dan terdapatnya agregat sel-sel radang (Gambar 3.1).

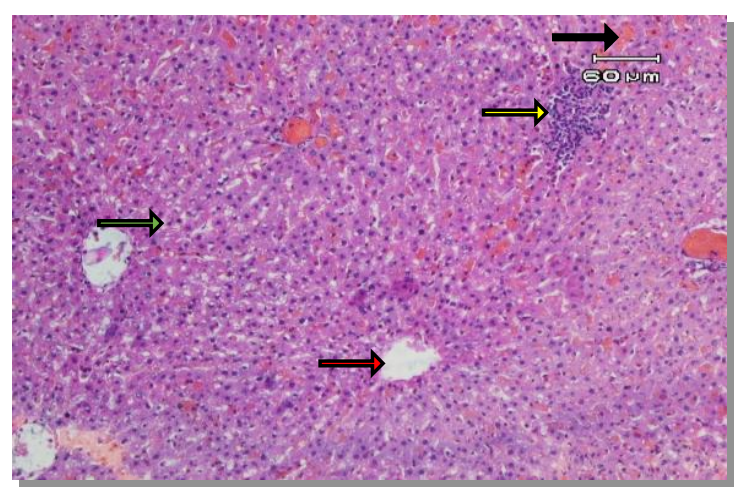

Gambar 3.1 Gambaran mikroskopik hati tikus wistar kelompok C (pembesaran 10x10). Steatosis hati lebih luas disertai peradangan dan tampak adanya proses regenerasi. Panah merah: pelebaran vena sentralis; panah kuning: agregat sel-sel radang; panah hitam: fibrin eritrosit; panah hijau: perlemakan sel hati makrovesikular

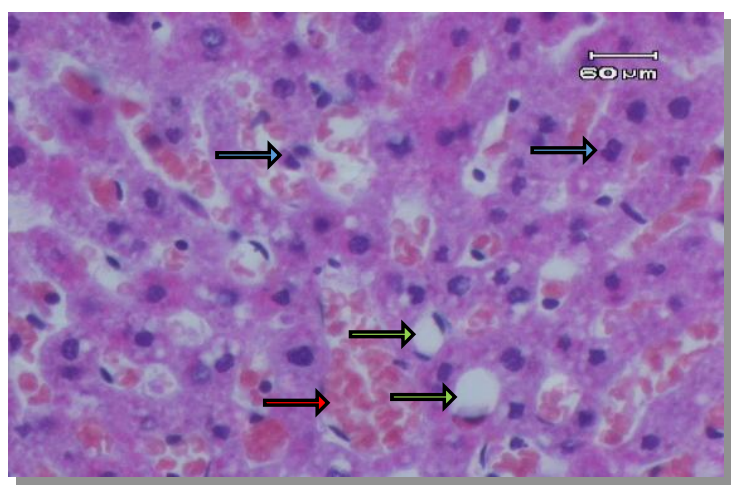

Gambar 3.2 Gambaran mikroskopik hati tikus wistar kelompok C (pembesaran 10x40). Panah merah: pelebaran vena sentralis; panah hijau: perlemakan sel hati makrovesikular panah biru: sel hati berinti ganda menandakan proses regenerasi telah dimulai.
Perlemakan jaringan hati tidak hanya terlihat di bagian perifer saja seperti pada kelompok B melainkan sudah lebih luas sampai mendekati vena sentralis. Gambaran degenerasi perlemakan juga sedikit berbeda dengan kelompok B dimana lebih didominasi oleh perlemakan makro dibandingkan mikrovesikular. Sel-sel hati juga sudah mulai beregenerasi dengan terlihat adanya sel hati yang mengandung sitoplasma yang sangat eosinofilik, inti sel membesar dan lebih hitam bahkan sudah ada sel yang berinti ganda (mengalami pembelahan sel) (Gambar 3.2).

\section{BAHASAN}

Metilprednisolon merupakan obat golongan kortikosteroid yang termasuk dalam kelompok adrenokortikosteroid sintetik. ${ }^{3}$ Steroid dianggap sebagai obat yang aman dan tidak diyakini dapat menyebabkan DILI, bahkan sering digunakan untuk terapi pasien hepatitis berat. ${ }^{4}$ Mekanisme metilprednisolon menyebabkan DILI sampai sekarang masih belum diketahui dengan jelas. ${ }^{5}$ Penelitian yang dilakukan ini bertujuan untuk melihat efek pemberian obat metilprednisolon terhadap gambaran histopatologik hati tikus wistar.

Hasil penelitian yang telah dilakukan menunjukkan adanya perubahan histologik hati pada kelompok tikus perlakuan yang diberikan metilprednisolon dosis rendah 2 $\mathrm{mg} /$ hari (Gambar 8) maupun dosis tinggi 4 mg/hari (Gambar 9) dibandingkan dengan kelompok tikus kontrol negatif (Gambar 7). Pada kelompok kontrol negatif gambaran histologiknya normal dan tidak ada kelainan struktural.

Secara umum, gambaran histopatologik hati tikus wistar pada kelompok perlakuan (kelompok $\mathrm{B}$ dan kelompok C) memberikan gambaran histopatologik yang mirip yaitu adanya steatosis mikro dan makrovesikular disertai dengan reaksi peradangan. Gambaran histopatologik yang diperoleh sama dengan gambaran histopatologik hati pada pasien dengan steatohepatitis. Drug-induced Steatohepatitis merupakan suatu cedera 
hati yang jarang ditemui dan diketahui hanya dicetuskan serta berkaitan dengan senyawa-senyawa tertentu termasuk metabolit obat. Keadaan ini mungkin disebabkan karena metilprednisolon dapat menginduksi terjadinya kerusakan mitokondria jika dosis obat telah melewati dosis terapeutik. ${ }^{10,11}$

Mekanisme utama kerusakan mitokondria melibatkan proses inihibisi beta-oksidasi asam lemak, fosforilasi oksidatif dan respirasi sel. Proses betaoksidasi merupakan salah satu pathway utama bagaimana lipid itu dimetabolisme dalam tubuh, dan apabila terjadi inhibisi pada proses tersebut, maka akan terjadi penumpukan asam lemak bebas dalam sel hati. Asam lemak bebas merupakan senyawa toksik. Akumulasi senyawa tersebut akhirnya akan mencetuskan alternative pathway oksidasi asam lemak yang dimediasi oleh sitokrom P2E1 (CYP2E1) di dalam sitosol dan juga peroksidasi lipid dalam peroksisom sel hati. CYP2E1 meningkatkan peroksidasi lipid dan sintesis asam dikarboksilat via aktivasi omega-oksidasi asam lemak yang kemudian akan merusak mitokondria. Hasilnya, sel hati akan mengalami cedera dan tampak membengkak. Inhibisi dari proses fosforilasi oksidatif dan respirasi sel juga merupakan keadaan toksik bagi mitokondria dan dapat menyebabkan pelepasan reactive oxygen species (ROS). Secara bersamaan, terjadilah proses penumpukan lemak intraseluler dan ROS tadi akan menyebabkan terbentuknya suatu lipid teroksidasi dan menginisiasi proses inflamasi yang kemudian akan berakhir pada keadaan steatosis maupun steatohepatitis. $^{10,11}$

Selain menyebabkan penumpukan lemak intrahepatik, metilprednisolon mungkin juga dapat memicu reaksi peradangan dengan mencetuskan terjadinya nekrosis sel-sel hati akibat kerusakan mitokondria oleh stres oksidatif yang ditandai dengan adanya pembengkakan sel dan kerusakan membran plasma. Reaktif metabolit dari metilprednisolon yang berikatan kovalen dengan protein selular diperkirakan menjadi penyebab terjadinya hepatotoksisitas. Reaktif metabolit obat yang terbentuk kemudian akan menyerang tiol bebas dan akan menyebabkan deplesi glutation (GSH) dalam sitosol maupun mitokondria. Glutation yang mengalami deplesi kemudian akan menyebabkan disfungsi mitokondria yang pada akhirnya akan menyebabkan nekrosis. Pelepasan komponen-komponen selular akibat terjadinya nekrosis akan mencetuskan suatu respon peradangan melalui pelepasan mediator pro-inflamasi seperti tissue/tumor necrosis factor (TNF)- $\alpha$, interferon (IFN)$\gamma$, interleukin (IL)-2, IL-4, IL-10 dan IL13. ${ }^{12-15}$

Selain gambaran steatosis dengan inflamasi, tampak juga sel-sel yang sudah mengalami regenerasi. Regenerasi sel tampak dimulai dari daerah dekat vena sentralis. Proses regenerasi sel hati sendiri bermula dari terinduksinya immediate-early (IE) genes seperti c-fos dan c-jun. Gen IE ini kemudian akan membawa sel hati dari fase G0 ke fase G1 dari siklus sel. Tingkat ekspresi gen IE ini sendiri sebagian besar diatur oleh sitokin-sitokin seperti TNF. Tumor necrosis factor selanjutnya berikatan dengan reseptornya pada sel Kupffer yang kemudian mengakibatkan peningkatan produksi IL-6. Setelah sel memasuki fase G1, sel akan mengikuti siklus sel sampai fase proliferasi yang diatur growth factor (GF) dimana yang paling berperan dalam proses ini adalah hepatocyte growth factor (HGF) yang terikat pada reseptor c-met. ${ }^{16}$ Proses transisi sel dari G1 menuju fase $\mathrm{S}$, melibatkan $\mathrm{Rb}$ phosphorylation yang meningkatkan ekspresi gen p107 dan cyclins D, E dan A. ${ }^{17}$ Selain itu, metabolisme dari asam amino juga turut meregulasi proliferasi sel hati melalui modulasi cyclin D1. ${ }^{18}$ Semua proses tersebut memungkinkan hati untuk melakukan regenerasi dan mengganti selsel yang telah rusak yang dalam hal ini dicetuskan oleh metilprednisolon..

Berdasarkan hasil penelitian ini, maka secara umum dapat dikatakan bahwa metilprednisolon baik dosis tinggi maupun dosis rendah (standar) dapat menyebabkan 
DILI berupa steatosis maupun steatohepatitis. Kedua kelompok perlakuan menunjukkan reaksi patologis terhadap pemberian metilprednisolon oral selama 14 hari berturut-turut. Berdasarkan pengamatan secara kualitatif, kelompok yang mendapatkan dosis metilprednisolon lebih tinggi, memiliki gambaran histopatologik hati yang lebih jelek. Penelitian ini telah memberikan gambaran yang dapat menambah informasi dan pengetahuan serta merupakan suatu pembuktian teori bahwa memang benar metilprednisolon dapat menyebabkan DILI bahkan hanya dengan dosis rendah yang diberikan dalam jangka waktu yang lama.

Namun penelitian ini masih memiliki beberapa kekurangan dan keterbatasan, antara lain belum adanya sumber informasi yang jelas mengenai mekanisme pasti dari metilprednisolon yang menyebabkan DILI. Penelitian yang dilakukan hanya mewakili tikus wistar jantan dan tidak memaparkan bagaimana respon hati terhadap metalprednisolon pada tikus wistar betina. Diperkirakan akan ada suatu perbedaan respon jaringan pada tikus wistar betina mengingat adanya estrous cycle yang dapat memengaruhi proses metabolisme obat melalui perubahan kadar hormon sex steroid. ${ }^{19}$ Dalam penelitian ini juga belum dietahui mekanisme mengapa perlemakan pada kelompok B hanya terbatas pada daerah perifer saja. Kemungkinan hal ini disebabkan karena metabolit obat metilprednisolon memang cenderung menyebabkan steatosis di daerah perifer atau mungkin juga dipengaruhi oleh proses regenerasi yang lebih dulu terjadi di dekat vena sentralis dibandingkan dengan daerah perifer karena aliran darahnya yang lebih sedikit.

\section{SIMPULAN}

Dari hasil penelitian dan bahsan dapat disimpulkan bahwa metilprednisolon oral dosis rendah $2 \mathrm{mg} / \mathrm{hari}$ dan dosis tinggi 4 $\mathrm{mg} /$ hari selama 14 hari pada tikus wistar dapat menyebabkan terbentuknya mikro dan makrovesikular steatosis disertai dengan reaksi inflamasi (steato-hepatitis).
Gambaran histopatologik hati kelompok tikus yang mendapatkan metilprednisolon oral dosis tinggi secara kualitatif lebih jelek dibandingkan kelompok yang menerima dosis rendah.

\section{SARAN}

1. Perlu dilakukan penelitian lebih lanjut dengan waktu yang bervariasi dan jumlah sampel yang lebih banyak untuk mengetahui perbandingan respon akut maupun kronik sel hati terhadap paparan metilprednisolon jangka panjang.

2. Perlu dilakukan penelitian lanjutan untuk mengetahui bagaimana mekanisme pasti metilprednisolon dalam menyebabkan DILI.

3. Perlu dilakukan penelitian yang serupa tetapi dengan sampel yang berbeda untuk melihat apakah ada perbedaan respon jaringan terhadap metilprednisolon pada tikus wistar betina.

\section{DAFTAR PUSTAKA}

1. Melamud B, Lurie Y, Goldin E, Levi I, Esayag Y. MethylprednisolonInduced Liver Injury: A Diagnostic Challenge. IMAJ. 2014;16:180-1.

2. Bell, LN Chalasani N. Epidemiology of Idiosyncratic Drug-Induced Liver Injury. Semin Liver Dis. 2009; 29:337-47.

3. Katzung, Bertram G. Farmakologi Dasar dan Klinik. Edisi ke-6. Chaidir Jusup et al, alih bahasa. Agoes A, editor. Jakarta: EGC; 1998.h.619-21.

4. Topal F, Ozaslan E, Akbulut S, Kucukazman M, Yuksel O, Altıparmak E. Methylprednisolone Induced Toxic Hepatitis. Ann Pharmacother. 2006;40:1868-71.

5. Gutkowski K, Chwist A, Hartleb M. Liver Injury Induced by High-Dose Methylprednisolone Therapy: A Case Report and Brief Review of Literature. Hepat Mon. 2011;(11):656-61.

6. Nair AB, Jacob S. A Simple Practice Guide for Dose Conversion Between Animals and Human. J Basic Clin Pharma. 2016; 7:27-31.

7. Alam SM, Kyriakides T, Lawden M, 
Newman PK. Methylprednisolone in multiple sclerosis: a comparison of oral with intravenous therapy at equivalent high dose. J Neurol Neurosurg Psychiatry. 1993;56(11):1219-20.

8. Medscape. Methylprednisolone. [cited 2016 Sep 7]. Available from: http://www.reference.medscape.com/ methylprednisolone.html

9. Kirdak T, Uysal E, Korun N. Assesment of Effectiveness of Different Doses of Methylprednisolone on Intraabdominal Adhesion Prevention. Ulus Travma Acil Cerrahi Derg. 2008; 14(3):188-91.

10.Schumacher J, Guo G. Mechanistic Review of Drug-Induced Steatohepatitis. Toxicoll Appl Phaemacol. 2015; 289(1):40-7.

11.Miyamura M, Yokota J, Saibara T. DrugInduced Nonalcoholic Steatohepatitis. The Pharmaceutical Society of Japan. 2016; 136(4):579-82.

12. Yuan L, Kaplowitz N. Mechanism of Drug-Induced Liver Injury. Clin Liver Dis. 2013; 17(4):507-18

13.Dawson S, Stahl S, Paul N, et al. In Vitro Inhibition of The Bile Salt Export Pump Correlates with Risk of Cholestatic Drug-Induced Liver Injury in Humans. Drug Metab
Dispos. 2012; 40(1):130-138.

14. Chen M, Suzuki A, Borlak J, Andrade RJ, Lucena MI. Drug-Induced Liver Injury: Interactions Between Drug Properties and Host Factors. Elsevier: Journal of Hepatology. 2015; 63:50314.

15.Kulmatycki KM, Jamali F. Drug Disease Interactions: Role of Inflammatory Mediators in Depression and Variability in Antidepressant Drug Response. J Pharm Pharmaceut Sci. 2006; 9(3):292-306.

16.Furchtgott LA, Chow CC, Periwal V. A Model of Liver Regeneration. Elsevier: Biophysical Journal. 2009; 96:3926-35.

17.Mao SA, Glorioso JM, Nyberg SL. Liver Regeneration. Transl Res. 2014 April ; 163(4): 352-62.

18.Nelsen CJ, Rickheim DG, Timchenko NA, et al. Transient Expression of Cyclin D1 Is Sufficient to Promote Hepatocyte Replication and Liver Growth in Vivo. Cancer Research. 2001; 61(23):8564-568.

19.Brandstetter Y. Kaplanski J, Leibson V, Ben-Zvi Z. The Effects of Estrus Cycle on Drug Metabolism in The Rat. European Journal of Drug Metabolism and Pharmacokinetics. 1986; 11:251. 